\title{
Psychometric Properties of the Spanish Language Version of the Stress in Children Questionnaire (SiC)
}

\author{
Propriedades Psicométricas da Versão em Língua Espanhola do Questionário \\ sobre Estresse em Crianças (SiC)
}

\author{
Alejandra Caqueo-Urízar ${ }^{*}, a$, Alfonso Urzúa $^{b} \&$ Walter Osika ${ }^{c}$ \\ ${ }^{a}$ Universidad de Tarapacá, Arica, Chile, ${ }^{b}$ Universidad Católica del Norte, Antofagasta, Chile \\ $\&{ }^{c}$ Department of Clinical Neuroscience, Karolinska Institutet, Stockholm, Sweden
}

\begin{abstract}
This study describes an analysis of the psychometric properties of a Spanish language version of the Stress in Children ( $\mathrm{SiC}$ ) questionnaire. A group of Chilean school children was evaluated. The results show a tested version of the mentioned questionnaire which consists of 16 items distributed across two factors (emotional well-being and sources of distress). Internal consistency indices (Cronbach's alpha-coefficients) were high. It is concluded there are appropriate psychometric properties for the Stress in Children questionnaire for this group of Chilean children. It is, therefore, a brief and easy to understand instrument of child assessment.

Keywords: Anxiety, stress, children, psychometric properties.
\end{abstract}

\begin{abstract}
Resumo
Este estudo descreve uma análise das propriedades psicométricas de uma versão em espanhol do questionário sobre estresse de crianças $(\mathrm{SiC})$. Foi avaliado um grupo de crianças escolares chilenas. Os resultados apresentam uma versão testada do questionário analisado composta por 16 itens distribuídos em dois fatores (bem-estar emocional e fontes de angústia). Os índices de consistência interna (coeficientes alfa de Cronbach) foram altos. Conclui-se a existência de propriedades psicométricas adequadas para o questionário sobre estresse de crianças com este grupo de escolares chilenos. Portanto, tem-se um instrumento de avaliação da criança breve e fácil de compreender.

Palavras-chave: Ansiedade, stress, crianças, propriedades psicométricas.
\end{abstract}

The existence of psychiatric disorders in childhood, due to their high continuity into adolescence and throughout adulthood, has been a topic of study in recent years, with anxiety posing one of the most obvious demands on mental health services (Esparza \& Rodríguez, 2009; López, Alcántara, Fernández, Castro, \& López, 2010).

Anxiety has been defined as a diffuse state of being uneasy or worried that can convert into a vicious circle that is difficult to break, leading to serious consequences. If to this are added current levels of stress experienced by children and adolescents resulting from intense routines and activities exceeding the frustration level, the net effect would explain the presence of anxiety in the child-adolescent population. Approximately $10 \%$ of minors and adolescents have anxiety disorders, ranging from $5.6 \%$ to $21 \%$, depending on the criteria employed

* Mailing address: Avenida 18 de Septiembre, Arica, Chile\#2222. E-mail: acaqueo@uta.cl, alurzua@ucn.cl, walter.osika@ki.se.

Acknowledgement: This research was funded by Fondo Nacional de Desarrollo Científico y Tecnológico (FONDECYT) - Project 1110472, by the Government of Chile. and the type of anxiety disorder studied (Anderson, 1994; Benjamin, Costello, \& Warren, 1990; Costello, Mustillo, Erkanli, Keeler, \& Angold, 2003; Kashani \& Orbvaschel, 1990; López et al., 2010) with an increase observed with age (Miguez \& Becoña, 2007).

Lupien, McEwen, Gunnar and Heim (2009) pointed out that risk factors for the development of stress reactions depend primarily on the genetic vulnerability of the individual, the exposure to adverse life events, the socioeconomic situation, disturbances in important relationships, problems with school, and the timing of stressful events (S. Brown, Nobling, Teufel, \& Birch, 2011; Lupien et al., 2009).

Other factors that can influence the manifestation of anxiety are related to cross-cultural differences. It is well known that the presentation of anxiety symptoms is affected by culture; this not only has an impact on adaptive behavior, but it may also affect how some psychopathological symptoms are formed and explained (Crane \& Campbell, 2000).

In a study where the characteristics of anxiety in Latin adolescents living in the United States where compared with Colombians living in Colombia, cultural diffe- 
rences in beliefs and perceptions that could affect the way children and adolescents express anxiety symptoms were found. These differences are related to how young Latinos expresses' their fears and anxieties. In the Latino culture, it is unacceptable to express negative emotions or psychological problems, as this is seen as a weakness of character and leads to shame and social stigma (Crane \& Campbell, 2000). In a study of Colombian and Australian children, it was found that Colombian children reported significant higher levels of anxiety, which the authors suggested could be explained by environmental factors and the higher levels of violence that these children experience daily, in contrast to the atmosphere perceived by Australian children who may feel physically more safe. In both countries girls reported higher levels of anxiety, and that the anxiety levels decrease by age (Crane \& Campbell, 2000; Derluyn, Broekaert, \& Schuyten, 2008).

In Chile, there is limited information on the epidemiology of anxiety symptoms in adolescents, and there are few instruments that facilitate the evaluation of these issues (Cova, Melipillán, Valdivia, Bravo, \& Valenzuela, 2007). Despite this, a study carried out in the South of Chile, points out that anxiety disorders are the most frequent diagnostic Group (18.9\%), decreasing to $8.7 \%$ to correct for disability criterion. To study specific diseases it is possible to observe higher prevalence of disorders anxiety of separation $(9.5 \%)$ and generalized anxiety disorder $(9.2 \%)$. However, to correct for disability criterion these down to $4.2 \%$ and $2.3 \%$ respectively. There is a higher percentage of presence of anxiety disorder in women than in men, with similar distribution among children from 4 to $11(19 \%)$ and adolescents from 12 to 18 (18.9) according to DSM-IV diagnosis (Vicente et al., 2010).

In Sweden and other european countries there has been a development of higher frequencies of reported ill health in children, adolescents, and young adults, particularly in older teenage girls (Hagquist, 2009, 2010; Haugland, Wold, Stevenson, Aaroe, \& Woynarowska, 2001; Hjern, Alfven, \& Ostberg, 2008; Schraml, Perski, Grossi, \& Simonsson-Sarnecki, 2011).

There are a considerable number of instruments available for evaluating anxiety in English as well as Spanishspeaking children and adolescents (Beidel \& Morris, 1995; Birmaher et al., 2008; Castrillón \& Borrero, 2005; Finch, Kendall, Montgomery, \& Morris, 1975; García-Pérez \& Magaz-Lago, 1995; García-Villamisar \& Yenes, 2002; March, Parker, Sullivan, Stallings, \& Conners, 1997; Ollendick, 1983; Reynolds \& Richmond, 1985; Sandín, Chorot, Santed, \& Valiente, 2002; Sandín, Valiente, Chorot, Santed, \& Sánchez-Arribas, 1999; Spence, 1997). The goal of these scales is to measure various aspects of anxiety such as: physical symptoms, avoidance, social anxiety and separation anxiety, as measured by the Multidimensional Anxiety Scale for Children (MASC; March et al., 1997), validated in Spanish by García-Villamisar and Yenses (2002). The revised Children's Manifest Anxiety Scale (Reynolds \& Richmond, 1997) measures excessive worry/sensitivity, social worries and concentration. The Anxiety Self Evaluation questionnaire validated in Mexico, basically measures physical and cognitive manifestations and somatic complaints.

There are similar scales that evaluate more specific aspects of anxiety such as: the Social Anxiety Scale for Children-revised (SASC-R; Sandín, Chorot, Valiente, Santed, \& Sánchez-Arribas, 1999); the Cuestionario de Ansiedad por Separacion Infantil (CASI-N; in English, the Separation Anxiety Questionnaire for Children, SASC) of Méndez, Espada, Orgilés, García-Fernández and Hidalgo (2008); the Escala para la Detección de la Ansiedad Social (EDAS; in English, scale for the detection of social anxiety) of Olivares and García-López (1998), validated in Chile by Vera-Villarroel et al. (2007); the Anxiety Sensitivity Index for Children (Sandín et al., 2002); as well as physiological indicators in response to anxiety measured on the Magallanes Anxiety Scale (García-Pérez \& Magaz-Lago, 1995); and state-trait anxiety measured using Spielberger's (Spielberger, 1973) State-Trait Anxiety Inventory for Children (STAIC), validated in Spanish by Castrillón and Borrrero in 2005. On the other hand, the Spence Children's Anxiety Scale (SCAS; Spence, 1997), the Spanish language version of which was developed by Hernández-Guzmán et al. (2010), is sensitive to changes induced by treatment.

On the other hand and relating directly to stress as a significant variable in the development of anxiety is observed a lesser amount of research in this issue. Stress is a phenomenon that is understood by the response to a demand, but in general is notorious as the negative affection and effects, also negative, produced when the person is exposed to a real environmental pressure, a situation of stress, for which lacks of time or resources for coping and resolved efficiently. Stress, to cease the pressure, or provide adequate response to the demand, should finish the emotional distress (Labrador \& Crespo, 1993).

Child stress is focused mainly in relation to diseases (Alfvén, 2012; Bailly, Wertz, Devos, Veignie, \& Turk, 2004; Chao, Wang, Chang, Wang, \& See, 2010; Kim et al., 2012; Mårild, Frostell, \& Ludvigsson, 2010; Röder, Kroonenberg, \& Boekaerts, 2003; E. M. Rodriguez et al., 2012; van Campen, Jansen, Steinbusch, Joels, \& Braun, 2012) and medical procedures and surgeries (Colville, \& Pierce, 2012; Jahrsdoerfer \& Kesser, 1995; Nelson \& Gold, 2012; Wells \& Schwebel, 1987). There has been less research in relation to daily stress to which children are exposed, even literature shows only some instruments such as: the Daily Life Stressor Scale (DLSS) developed by Kearney Drabman and Beasley (1993); Desi-Lewis's Life Events and Coping Inventory (Desi-Lewis, 1988); the Inventario Infantil de Estresores Cotidianos (IIEC; The Child Daily Stressor Inventory), developed by Trianes et al. (2009) of the University of Málaga; the Maastricht University Stress Instrument for Children (MUSIC; Kraag, Meesters, Fekkes, Kok, \& Huijer Abu-Saad, 2008) and the Stress in Children (Sic) questionnaire developed by Osika, 
Caqueo-Urízar, A., Urzúa, A. \& Osika, W. (2014). Psychometric Properties of the Spanish Language Version of the Stress in Children Questionnaire (SiC).

Friberg and Währborg (2007), an instrument yet to be tested in Spanish, which was designed with the objective of detecting levels of stress in school children from 9 to 12 years old. As pointed out by Kraag, Van Breukelen, Kok and Hosman (2009), daily stressors, especially when experienced cumulatively, have been found to be associated with psychological maladjustment, including behavioral problems, risktaking behavior, and depressive symptoms (Ames et al., 2005; Compas, Connor-Smith, Saltzman, Harding-Thomsen, \& Wadsworth, 2001; Eriksen \& Ursin, 2004; Gillander \& Hammarström, 2003; Hampel \& Petermann, 2005; Torsheim et al., 2005; Ursin, 1997).

Other studies have shown that the relationship between stress and psychological symptoms is highly complex. Stress, anxiety and depression have overlapping symptoms, with stress being more strongly correlated with anxiety and depression relative to the correlation between anxiety and depression. In fact, stress, anxiety and depression may represent three domains of continuously distributed phenomena (T. A. Brown, Chorpita, Korotitsch, \& Barlow, 1997; Cuijpers, 1998; De Beurs, van Dyk, Marquenie, Lange, \& Blong, 2001; Lovibond, \& Lovibond, 1995, in Kraag et al., 2009).

Considering the diverse social changes, such as economic crises and immigration, as well as the natural disasters that children currently experience in various parts of the world, a Spanish language version of an instrument is needed to enable measuring the consequences of psychosocial stress.

The objective of this research was to study the psychometric properties of the Stress in Children (Sic) questionnaire in a sample of boys and girls of the Chilean population. For the purposes of this study, stress will be defined as a concept that includes various factors, psychological as well as somatic, and high levels of the latter are associated with negative consequences of emotional and psychopathological health (Jose \& Ratcliffe, 2004; Seiffge-Krenke, 2000; Steer, Kumar, Beck, \& Beck, 2001; Trianes et al., 2009).

\section{Method}

\section{Subjects}

Study participants included 1678 individuals including $765(45.6 \%)$ boys and $913(54.4 \%)$ girls with ages between 8 and 18 , and a mean of 11.9 years $(S D=2.75)$ from public, private and subsidized (state-supported public) high schools. Since the study was conducted in two steps, the database was divided into two parts. The first group was for the purpose of performing preliminary analyses and consisted of 600 subjects of which 281 (46.8\%) were males and $319(53.2 \%)$ were females, with an age range from 8 to 18 years and a mean age of 12 years $(S D=2.68)$. The second group was made up by 1078 subjects of which 484 (44.9\%) were males and 594 (55.1\%) were females, with an age range from 8 to 18 years and a mean age of 11.9 years $(S D=2.78)$.

\section{Instrument}

Stress in Children Questionnaire (SiC; Osika et al., 2007). This easily self-administered questionnaire for children 9 to 12 years old was designed with the objective of detecting levels of perceived anxiety and the presence of symptoms or low levels of well-being as well as important aspects related to social confrontation and support. These factors can be considered part of a higher order dimension of subjective health, such as stress (Osika et al., 2007).

The questionnaire consists of 21 items that are scored on a 4-point Likert scale: none (0), sometimes (1), almost always (2) and always (3). An overall score is obtained by summing the points obtained for the 21 items, with a greater number of points indicating a higher degree of perceived stress. The mean \pm standard deviation in a normal Swedish population was $2.05 \pm .41$ (girls $=1.99$ \pm .42 , boys $=2.15 \pm .37$ ) with no significant differences detected between sexes.

Prior factorial analysis showed the existence of three factors: Anxiety (distress), lack of well-being, and lack of social support (Osika et al., 2007).

The $\mathrm{SiC}$ contains three questions about common symptoms of potential psychosomatic origin; headache, stomach pain, and difficulties falling asleep at night. A statistically significant association was found between the global mean score of the SiC questionnaire and two of these symptoms, stomach pain $(r=.356, r 2=.127, p$ $=.001)$ and difficulties falling asleep at night $(r=.505$, $r 2=.255, p=\leq .001)$.

This questionnaire has high internal consistency (Cronbach's alpha $=.86$ ) and shows strong association with the scales of the Beck Youth Inventories of Emotional and Social Impairment (BYI; Desi-Lewis, 1988).

\section{Procedure}

First of all, authorization was obtained from the author of the instrument to conduct the study. Second, the items were translated with subsequent back-translation by two persons whose native language was English. Third, approval for the study was obtained from the Ethics Committee of the Universidad Católica del Norte.

Following this process, participation by the Principal of each High School was requested in writing, and informed consent was requested of the parents.

Participants completed the Stress in Children questionnaire in groups in their own class rooms. The questionnaire was administrated by last year psychology students who oversaw the evaluation process at all time to answer any questions about the instrument. The parents signed the informed consent form, in which the objectives of the study and the voluntary nature of participation were explained.

\section{Data Analysis}

Two stages of analysis with different samples were made; the steps are specified later. The Statistical Package 
for the Social Sciences (SPSS version 15.0) was utilized for the statistical analysis. Analyses performed included a reliability analysis of the instrument, items analysis, and confirmatory factor analysis.

\section{Results}

Step 1 Preliminary Analyses

The correlation was calculated between every item and all other items for the 21 original items of the scale, to obtain a Cronbach's alpha of .77.

It was decided to eliminate all items with an item-total scale correlation below .20, which eliminated the items: "I get headaches" (.18), "I get stomach pains" (.13), "The other kids tease me" (.09), "Sometimes I can't manage the things I have to do" (.09) and "When I'm sad I show it" (.15).

The remaining 16 items had a total correlation with all other items of between .24 and .60 and a total-scale alpha of .80 . These 16 items were subjected to exploratory factor analysis by the method of principal components extraction with Varimax rotation.
The KMO index of sample size adequacy (.83) as well as Bartlett's test of sphericity $X^{2}(120)=1850.937$, $p<.001)$ supported the appropriateness of the analysis. A five-component solution was obtained that explained $57 \%$ of the variance. Considering the percentage of variance explained and the scree plot, it was opted to extract a two-factor solution, which explained $37 \%$ of the variance (Factor $1=19.18 \%$; Factor $2=18.38 \%$ ). The following four items, which either had a factor loading below .3 or else loaded indistinctly on both factors, were eliminated: "I fall asleep easily at night", "Things work out as I have planned (thoughts)", "When I have a hard time there is an adult to talk to", "If anybody teases me, I will protest".

The remaining components were grouped into two factors that explained $42.8 \%$ of the variance (Factor $1=21.42 \%$; Factor $2=21.37 \%$ ).

These two factors, even though with factor structure different from that originally proposed by Osika et al. (2007), had internal consistency and construct validity, and were denoted the Emotional well-being and Sources of distress factors. Table 1 shows the loading of the items on these factors.

Table 1

Matrix of Rotated Components

Emotional well-being Sources of distress

\begin{tabular}{lll}
\hline I get angry & Me da rabia & .547 \\
I like going to school & Me gusta ir al colegio (escuela) & .797 \\
I feel calm and happy & Me siento tranquilo y feliz & .556 \\
I feel lonely & Me siento solo & .700 \\
I get sad & Me siento triste & .719 \\
I like being at school & Me gusta estar en el colegio (escuela) & .612 \\
I feel calm & Me siento tranquilo & .663 \\
I feel happy & Me siento feliz & \\
When I am happy I show it & Cuando estoy feliz lo demuestro \\
$\begin{array}{l}\text { Things work out as I have } \\
\text { planned }\end{array}$ & Consigo las metas que me propongo \\
$\begin{array}{l}\text { When I have a hard time, it } \\
\text { helps being with my friends } \\
\text { It is easy for me to concentrate } \\
\text { during lessons at school }\end{array}$ & $\begin{array}{l}\text { Cuanto tengo problemas me ayuda concentrarme durante } \\
\text { las clases en la escuela }\end{array}$ & .448 \\
\hline
\end{tabular}


Caqueo-Urízar, A., Urzúa, A. \& Osika, W. (2014). Psychometric Properties of the Spanish Language Version of the Stress in Children Questionnaire (SiC).

Table 2

Item-Total Scale and Item-Factor Correlations

Item-total scale Item-factor

correlation correlation

Emotional well-being

I get angry

Me da rabia

.322

I feel calm and happy

Me siento tranquilo y feliz

.606

I feel lonely

Me siento solo

.339

I get sad

Me siento triste

.343

I feel calm

Me siento tranquilo

.586

I feel happy

Me siento feliz

Sources of distress

I like going to school

Me gusta ir al colegio(escuela)

I like being at school

Me gusta estar en el colegio (escuela)

.450

When I am happy I show it

Cuando estoy feliz lo demuestro

.396

Things work out as I have planned

Consigo las metas que me propongo

.436

When I have a hard time it helps

Cuanto tengo problemas me ayuda

.366

being with my friends

estar con mis amigos

Es fácil concentrarme durante

.375

.342

It is easy for me to concentrate

las clases en la escuela

This factor solution is the one utilized in Step 2.

\section{Discussion}

Step 2

The last analyses were performed on 1080 subjects. The correlations of each item with all other scale items and of each item with its factor are given in Table 2. Cronbach's alpha-coefficients were .80 for the total scale, .77 for the Emotional well-being factor, and .69 for the Sources of distress factor.

In order to evaluate the fit of the data to the theoretical two factor model, a confirmatory type of factor analysis was performed. The results of fit indices obtained for the model show $X^{2}=627.703(\mathrm{gl}=43)$.

Although the Comparative Fit Index $(\mathrm{CFI}=.78)$ and Normal Fit Index (NFI $=.76$ ) had values below .90 (the value considered to indicate a good or better fit; Bentler \& Dudgeon, 1996), they were near that value. A similar result was obtained for RMSEA = .11 (Root Mean Square Error of Approximation) indices, which were significant with values below .08 (Browne \& Cudeck, 1993) and with the goodness of fit index $(\mathrm{GFI}=.88)$, which represents the combined fit (values between $0=$ bad fit and $1=$ perfect fit).
The factor structure making up Spanish language version of the Stress in Children Questionnaire, indicates the presence of two factors that are characterized by the first one including symptomatology associated with well-being, and the second one, daily stressors experienced by minors.

These factors are in agreement with the literature regarding cognitive symptoms relating to anxiety and worrying (i.e., the mental interpretation one makes of his own situation); in other words, the factors reveal as part of anxiety, the youth's personal appreciation of the situation in which he finds himself. In the case of the first factor measured by this instrument, assessments such as: "I feel lonely"; "I get sad"; "I feel calm", would be expressive of what for the minor means a greater or lesser degree of emotional well-being.

The second factor, denoted Sources of distress, basically includes responses that deal with daily stressors, with high school being one of those with the highest factor loading. Thus, as in previous studies, exposure to certain stressing environmental factors, as proposed by Rodríguez 
et al. (S. Brown et al., 2011; Rodríguez \& Martínez, 2001), may become a predisposing factor for the development of an emotional problem, especially when some degree of vulnerability is present (Diez \& Sánchez, 2000; Esparza \& Rodríguez, 2009). Other studies have suggests a predisposition which, in combination with high levels of stress, inadequate appraisal, poor coping and insufficient adequate support, may increase one's risk for developing health problems (Ingram \& Luxton, 2005; Rutter, KimCohen, \& Maughan, 2006).

Specifically, exposure to stressors related to scholastic performance are associated with the manifestation of anxiety, and likewise, exposure to situations such as the evaluations to which the boys and girls see themselves exposed (academic as well as those relating to conflict resolution with their peers at school) constitute a significant stressor (Barraza, 2006; Esparza \& Rodríguez, 2009; Oros \& Vogel, 2005; Pellicer, Salvador, \& Benet, 2002).

The latter can lead to emotional exhaustion, as proposed by Garcés in 1995 and as well by Laursen et al., in 2010, who pointed out that when children in school environments are exposed to high demands they may perceive lack of control, generating frustration, apathy and anguish within themselves, with extreme overload also being observed relative to demands, which may produce emotional exhaustion from school or "School Burnout", with associated academic failure, dropping out, academic phobia and depression (Laursen et al., 2010). High expectations of parents and teachers also can significantly influence school burnout (Yildirim \& Ergene, 2003).

Reducing the items in the original version was another result obtained by analyzing the psychometric properties of the Spanish version of the questionnaire. Reducing the items from 21 to 16 provided an even shorter instrument that will facilitate wider use of this type of self-administered test in Chilean boys and girls, of particular interest because low reading comprehension is a major educational problem in this country (Fuentes, 2009; Ramos, 2006; Rosas, Jiménez, Rivera, \& Yáñez, 2003).

Despite the reduction in items, the instrument has adequate reliability and validity (factor structure); there is, however, a need to continue adapting instruments to the Spanish language to achieve early detection and care for these minors (Aypay, 2011; Spielberger, 1973).

\section{Conclusion}

The Spanish language version of the Stress in Children Questionnaire has acceptable psychometric properties and includes 16 of the original 21 items, making it a short and easily understood scale.

The instrument was demonstrated to have adequate factor structure which, in spite of the difference from the original factor structure, has internal construct consistency in addition to a high Cronbach's alpha-coefficient, attesting to its reliability.
The study presents a series of limitations, first of all, many more girls and boys were invited to participate in this research than chose to take part, which could finally, introduces selection bias. Secondly, family socio-economic status was not formally assessed, even though the community where the study was predominantly middle-class. Third this study only reports on children older than 8 years, this is because there is a lack of validated anxiety questionnaires for younger population. As a consequence, the study cannot draw conclusions on younger children, although they also express symptoms of anxiety.

Future studies, like the one conducted by Osika et al. (2007), should consider saliva cortisol measurements as a stress indicator.

It is necessary the replication of the study with a large sample whereas a greater diverse geographical origin within Latin America enable as generalization of the results. In addition, results obtained for populations that are as dissimilar as those in Scandinavian and Latin American countries need to be examined.

Finally, longitudinal data are necessary to correctly evaluate the development of anxiety symptoms and their consequences during the life-span.

\section{References}

Alfvén, G. (2012). Recurrent pain, stress, tender points and fibromyalgia in childhood: An exploratory descriptive clinical study. Acta Paediatrica, 101(3), 283-291.

Ames, S. C., Offord, K. P., Nirelli, L. M., Patten, C. A., Friedrich, W. N., \& Hurt, R. D. (2005). Initial development of a new measure of minor stress for adolescents: The adolescent minor stress inventory. Journal of Youth and Adolescence, 34, 207-219.

Anderson, J. (1994). Epidemiological issues. In T. H. Ollendick, N. J. King, \& W. Yule (Eds.), International handbook of phobic and anxiety disorders in children and adolescents (pp. 43-65). New York: Plenum Press.

Aypay, A. (2011). Elementary school student burnout scale for grades 6-8: A study of validity and reliability. Educational Sciences: Theory \& Practice, 11(2), 520-527.

Bailly, D., Wertz, E., Devos, P., Veignie, L., \& Turck, D. (2004). Une mesure du stress des adolescents hospitalisés. Archives de Pédiatrie, 11, 1430-1437.

Barraza, A. (2006). Un modelo conceptual para el estudio del estrés académico. Recuperado en http://www.psicologíacientífica.com/bv/psicología-167-1-un-modelo-conceptualpara-el-estudio-del-estrés-académico.html

Beidel, D., \& Morris, T. (1995). Social phobia. In J. March (Ed.), Anxiety disorders in children and adolescents (pp. 181-211). New York: The Guilford Press.

Benjamin, R., Costello, E., \& Warren, M. (1990). Anxiety disorders in a pediatric simple. Journal of Anxiety Disorders, 4, 293-316.

Bentler, P., \& Dudgeon, P. (1996). Covariance structure analysis: Statistical practice, theory, and directions. Annual Review of Psychology, 47, 563-592.

Birmaher, B., Khetarpal, S., Brent, D., Cully, M., Balach, L., Kaufman, J., ... Vírseda J. (2008). Estructura factorial de una escala para evaluar ansiedad en una muestra de adolescentes. Psicología Iberoamericana, 16(1), 69-73. 
Caqueo-Urízar, A., Urzúa, A. \& Osika, W. (2014). Psychometric Properties of the Spanish Language Version of the Stress in Children Questionnaire (SiC).

Brown, S., Nobling, B., Teufel, J., \& Birch, D. (2011). Are kids too busy? Early adolescents' perception of discretionary activities, overscheduling, and stress. Journal of School Health, 81(9), 574-580.

Brown, T. A., Chorpita, B. F., Korotitsch, W., \& Barlow, D. H. (1997). Psychometric properties of the Depression Anxiety Stress Scales (DASS) in clinical samples. Behavior Research and Therapy, 35, 79-89.

Browne, M., \& Cudeck, R. (1993). Alternative ways of assessing model fit. In K. A. Bollen \& J. S. Long (Eds.), Testing Structural Equation Models (pp. 136-162). Newbury Park, CA: Sage.

Castrillón, D., \& Borrero, P. (2005). Validación del inventario de ansiedad estado-rasgo (STAIC) en niños escolarizados entre los 8 y 15 añosActa Colombiana de Psicología, 13, 79-90.

Chao, K. Y., Wang, H. S., Chang, H. L., Wang, Y. W., \& See, L. C. (2010). Establishment of the reliability and validity of the Stress Index for Children or Adolescents with Tourette Syndrome (SICATS). Journal of Clinical Nursing, 19(3-4), 332-340.

Colville, G., \& Pierce, C. (2012). Patterns of post-traumatic stress symptoms in families after pediatric intensive care. Intensive Care Medicine, 38(9), 1523-1531.

Compas, B. E., Connor-Smith, J. K., Saltzman, H., HardingThomsen, A., \& Wadsworth, M. E. (2001). Coping with stress during childhood and adolescence: Problems, progress, and potential in theory and research. Psychological Bulletin, 127, 87-127.

Costello, E., Mustillo, S., Erkanli, A., Keeler, G., \& Angold, A. (2003). Prevalence and development of psychiatric disorders in childhood and adolescence. Archives of General Psychiatry, 60, 837-844.

Cova, F., Melipillán, R., Valdivia, M., Bravo, E., \&Valenzuela, B. (2007). Sintomatología depresiva y ansiosa en estudiantes de enseñanza media. Revista Chilena de Pediatría, 78(2), 151-159.

Crane, A., \& Campbell, M. (2000). Una comparación transcultural de síntomas de la ansiedad entre niños colombianos y australianos. Electronic Journal of Research in Educational Psychology, 8(2), 497-516.

Cuijpers, P. (1998). Het belang van subklinische depressie. Tijdschrift voor Psychiatrie, 40, 635-640.

De Beurs, E., van Dyck, R., Marquenie, L. A., Lange, A., \& Blonk, R. W. B. (2001). De DASS: Een vragenlijst voor het meten van depressie, angst en stress. Gedragstherapie, $34,35-53$.

Derluyn, I., Broekaert, E., \& Schuyten, G. (2008). Emotional and behavioural problems in migrant adolescentsin Belgium. European Society for Child and Adolescent Psychiatry, 17(1), 54-62.

Desi-Lewis, J. (1988). The life and coping inventory: An assessment of stress in children. Psychosomatic Medicine, 50, 484-499.

Diez, C., \& Sánchez, L. (2000). Trastornos médicos [Medical disorders]. In J. Vallejo \& C. Gastó (Eds.), Trastornos afectivos: ansiedad y depresión (pp. 51-100). Barcelona, España: Salvat.

Eriksen, H., \& Ursin, H. (2004). Subjective complaints, sensitization, and sustained cognitive activation. Journal of Anxiety Disorders, 56, 445-448.

Esparza, N., \& Rodríguez, M. (2009). Factores contextuales del desarrollo infantil y su relación con los estados de ansiedad y depresión. Revista Diversitas - Perspectivas en Psicología, $5(1), 47-65$.
Finch, A., Kendall, P., Montgomery, L., \& Morris, T. (1975). Effects of two types of failure on anxiety. Journal of Abnormal Psychology, 84(5), 583-587.

Fuentes, L. (2009). Diagnóstico de comprensión lectora en educación básica en Villarrica y Loncoche, Chile. Perfiles Educativos, 125, 23-37.

Garcés, E. (1995). Burnout en niños y adolescentes: un nuevo síndrome en psicopatología infantil. Psicothema, 7(1), 33-40.

García-Pérez, E., \& Magaz-Lago, A. (1995). Escala Magallanes de Ansiedad (Magallanes Anxiety Scale). Bilbao, España: Grupo Albor-Cohs.

García-Villamisar, D., \& Yenes, A. (2002). Estructura de los síntomas de ansiedad en la infancia. Un estudio exploratorio a través de la Multidimensional Anxiety Scale for ChildrenSpanish versión (MASC-SV). Informaciones Psiquiátricas, 23(2), 45-58

Gillander, K., \& Hammarström, A. (2003). Do changes in the psychosocial school environment influence pupils' health development? Results from a three-year follow-up study. Scandinavian Journal of Public Health, 31, 169-177.

Hagquist, C. (2009). Psychosomatic health problems among adolescents in Sweden: Are the time trends gender related? European Journal of Public Health, 19(3), 331-336.

Hagquist, C. (2010). Discrepant trends in mental health complaints among younger and older adolescents in Sweden: An analysis of WHO data 1985-2005. Journal of Adolescent Health, 46(3), 258-264.

Hampel, P., \& Petermann, F. (2005). Age and gender effects on coping in children and adolescents. Journal of Youth and Adolescence, 34, 73-83.

Haugland, S., Wold, B., Stevenson, J., Aaroe, L. E., \& Woynarowska, B. (2001). Subjective health complaints in adolescence. A cross-national comparison of prevalence and dimensionality. European Journal Public Health, 11(1), 4-10.

Hernández-Guzmán, L., Bermúdez-Ornelas, G., Spence, S., González, J., Aguilar, J., \& Gallegos, J. (2010). Versión en español de la escala de ansiedad para niños de Spence (SCAS). Revista Latinoamericana de Psicología, 42(1), 13-24

Hjern, A., Alfven, G., \& Ostberg, V. (2008). School stressors, psychological complaints and psychosomatic pain. Acta Paediatrica, 97(1), 112-7.

Ingram, R. E., \& Luxton, D. D. (2005). Vulnerabilitystress models. In B. L. Hankin \& J. R. Z. Abela (Eds.), Development of psychopathology (pp. 32-47). Thousand Oaks, CA: Sage.

Jahrsdoerfer, R. A., \& Kesser, B. W. (1995). Issues on aural atresia for the facial plastic surgeon. Facial Plastic Surgery, 11(4), 274-277.

Jose, P., \& Ratcliffe, V. (2004). Stressor frequency and perceived intensity as predictors of internalizing symptoms: Gender and age differences in adolescence. New Zealand Journal of Psychology, 33, 145-154.

Kashani, J., \& Orbvaschel, H. (1990). A community study of anxiety in children and adolescents. American Journal of Psychiatry, 147, 313-318.

Kearney, C., Drabman, R., \& Beasley, J. (1993). The trial of childhood: The development, reliability and validity of the Daily Life Stressors Scale. Journal of Child and Family Studies, 2, 371-388.

Kim, Y. H., Jung, H. J., Kang, S. I., Park, K. T., Choi, J. S., Oh, S. H., \& Chang, S. O. (2012) Tinnitus in children: Association with stress and trait anxiety. The Laryngoscope, 122(10), 2279-2284 
Kraag, G., Meesters, C., Fekkes, M., Kok, G., \& Huijer AbuSaad, H. (2008). The Development of MUSIC, a short stress symptoms questionnaire for preadolescents. Unpublished manuscript, Maastricht University, Maastricht, Belgium.

Kraag, G., Van Breukelen, J., Kok, G., \& Hosman, C. (2009). "Learn Young, Learn Fair", a stress management program for fifth and sixth graders: Longitudinal results from an experimental study. Jounal of Child Psychology and Psychiatry, 50(9), 1185-1195.

Labrador, F., \& Crespo, M. (1993). Estrés, trastornos fisiológicos. Madrid, España: Eudema.

Laursen, B., Bukowski, W., Nurmi, J., Marion, D., Salmela-Aro, K., \& Kiuru, N. (2010). Opposites detract: Middle school peer group antipathies. Journal of Experimental Child Psychology, 106, 240-256.

López, C., Alcántara, M., Fernández, V., Castro, M., \& López, J. (2010). Características y prevalencia de los problemas de ansiedad, depresión y quejas somáticas en una muestra clínica de 8 a 12 años, mediante el CBCL (Child Behavior Check List). Anales de Psicología, 26(2), 325-334.

Lovibond, P. F., \& Lovibond, S. H. (1995). The structure of negative emotional states: Comparison of the Depression Anxiety Stress Scales (DASS) with the Beck Depression and Anxiety Inventories. Behavior Research and Therapy, 33, 335-344.

Lupien, S., McEwen, B., Gunnar, M., \& Heim, C. (2009). Effects of stress throughout the lifespan on the brain, behaviour and cognition. Nature Reviews Neuroscience, 10(6), 434-445.

March, J., Parker, J., Sullivan, K., Stallings, P., \& Conners, C. (1997). The Multidimensional Anxiety Scale for Children (MASC): Factor structure, reliability and validity. Journal of the American Academy of Child \& Adolescent Psychiatry, 36(4), 554-565.

Mårild, K., Frostell, A. S., \& Ludvigsson, J. F. (2010). Psychological stress and coeliac disease in childhood: A cohort study. BMC Gastroenterology, 10, 106.

Méndez, F., Espada, J., Orgilés, M., García-Fernández, J., \& Hidalgo, M. (2008). Psychometric properties and diagnostic ability of the Separation Anxiety Scale for Children (SASC). European Child Adolescent Psychiatry, 17(6), 365-372.

Miguez, M., \& Becoña, E. (2007). Ansiedad y juego problema en escolares. Ansiedad y Estrés, 13(1), 41-50.

Nelson, L. P., \& Gold, J. I. (2012). Posttraumatic stress disorder in children and their parents following admission to the pediatric intensive care unit: A review. Pediatric Critical Care Medicine, 13(3), 338-347.

Olivares, J., \& García-López, L. (1998). Escala para la Detección de la Ansiedad Social. Unpublished manuscript.

Ollendick, T. (1983). Reliability and validity of the revised Fear Survey Schedule for Children (FSSC-R). Behaviour Research and Therapy, 21, 685-692.

Oros, L., \& Vogel, G. (2005). Eventos que generan estrés en la infancia: diferencias por sexo y edad. Enfoques, 17, 85-101.

Osika, W., Friberg, P., \& Währborg, P. (2007). A new short self-completion questionnaire to assess stress in children. International Journal of Behavioral Medicine, 14, 108-117.

Pellicer, O., Salvador, A., \& Benet, I. (2002). Efectos de un estresor académico sobre las respuestas psicológica e inmune en jóvenes. Psicothema, 14(2), 317-322.

Ramos, C. (2006). Elaboración de un instrumento para medir comprensión lectora en niños de octavo año básico. Onomázien, 14, 197-210.

Reynolds, C. R., \& Richmond, B. O. (1985). Revised Children's Manifest Anxiety Scale. Los Angeles, CA: Western Psychological Services.
Reynolds, C. R., \& Richmond, B. (1997). Escala de ansiedad manifiesta en niños, ed. revisada, CMAS-R Manual. [Children's Manifest Anxiety Scale, revised edition, CMAS-R Manual]. Mexico City, Mexico: Manual Moderno.

Röder, I., Kroonenberg, P. M., \& Boekaerts, M. (2003). Psychosocial functioning and stress-processing of children with asthma in the school context: Differences and similarities with children without asthma. The Journal of Asthma, 40(7), 777-787.

Rodriguez, E. M., Dunn, M. J., Zuckerman, T., Vannatta, K., Gerhardt, C. A., \& Compas, B. E. (2012). Cancer-related sources of stress for children with cancer and their parents. Journal of Pediatric Psychology, 37(2), 185-197.

Rodríguez, M., \& Martínez, N. (2001). Trastorno de ansiedad generalizada y trastorno de pánico en niños y adolescentes. In V. E. Caballo \& M. A. Simon MA. (Eds.), Manual de psicología clínica infantil y del adolescente: trastornos generales [Manual of child and adolescent clinical psychology: General disorders] (pp. 93-120). Madrid, España: Pirámide.

Rosas, M., Jiménez, P., Rivera, R., \& Yáñez, M. (2003). Estudio descriptivo de estrategias de comprensión lectora en estudiantes de 5 y 8 año básico de la comuna de Osorno. Revista Signos, 36(54), 235-247.

Rutter, M., Kim-Cohen, J., \& Maughan, B. (2006). Continuities and discontinuities in psychopathology between childhood and adult life. Journal of Child Psychology and Psychiatry, 47, 276-295.

Sandín, B., Chorot, P., Santed, M., \& Valiente, R. (2002). Análisis factorial confirmatorio del Índice de Sensibilidad a la Ansiedad para Niños. Psicothema, 14(2), 333-339.

Sandín, B., Chorot, P., Valiente, R., Santed, M., \& SánchezArribas, C. (1999). Estructura factorial de la escala de ansiedad social para niños-revisada (SASC-R). Revista de Psicopatología y Psicología Clínica, 4, 105-113.

Sandín, B., Valiente, R., Chorot, P., Santed, M., \& SánchezArribas, C. (1999). Escala de ansiedad social para niñosrevisada (SASC-R): fiabilidad, validez y datos normativos. Análisis y modificación de conducta. Behavior Analysis and Modification, 25(104), 827-847.

Schraml, K., Perski, A., Grossi, G., \& Simonsson-Sarnecki, M. (2011). Stress symptoms among adolescents: The role of subjective psychosocial conditions, lifestyle, and self-esteem. Journal of Adolescent, 34(5), 987-996.

Seiffge-Krenke, I. (2000). Causal links between stressful events, coping style and adolescent symptomatology. Journal of Adolescent, 23, 675-691.

Spence, S. (1997). Structure of anxiety symptoms among children: A confirmatory factor-analytic study. Journal of Abnormal Psychology, 106, 280-297.

Spielberger, C. (1973). Inventario de ansiedad estado-rasgo para niños, STAIC. Palo Alto, CA: Consulting Psychologists Press.

Steer, R., Kumar, G., Beck, J., \& Beck, A. (2001). Evidence for the construct validities of the Beck Youth Inventories with child psychiatric outpatients. Psychological Reports, 89, 559-565.

Torsheim, T., Ravens-Sieberer, U., Hetland, J., Valimaa, R., Danielson, M., \& Overpeck, M. (2005). Cross-national variation of gender differences in adolescent subjective health in Europe and North America. Social Science \& Medicine, 62, 815-827.

Trianes, M., Blanca, M., Fernández, F., Escobar, M., Maldonado, E., \& Muñoz A. (2009). Evaluación del estrés infantil: Inventario Infantil de Estresores Cotidianos (IIEC). Psicothema, 21(4), 598-603. 
Caqueo-Urízar, A., Urzúa, A. \& Osika, W. (2014). Psychometric Properties of the Spanish Language Version of the Stress in Children Questionnaire (SiC).

Ursin, H. (1997). Sensitization, somatization, and subjective health complaints. International Journal of Behavioral Medicine, 4, 105-116.

van Campen, J. S., Jansen, F. E., Steinbusch, L. C., Joels, M., \& Braun, K. P. (2012). Stress sensitivity of childhood epilepsy is related to experienced negative life events. Epilepsia 53(9), $1554-1562$.

Vera-Villarroel, P., Olivares-Rodríguez, J., Kuhne, W., Alcázar, A., Santibáñez, C., \& López-Pina, J. (2007). Propiedades psicométrica de la Escala para la Detección de la Ansiedad Social (EDAS) en una muestra de adolescentes chilenos. International Journal of Clinical Health Psychology, 7(3), 795-806.

Vicente, B., Saldivia, S., Rioseco, P., De La Barra, F., Valdivia, M., Melipillan, R., ...Pihan, R. (2010). Epidemiología de trastornos mentales infanto-juveniles en la Provincia de Cautín. Revista Médica de Chile, 138, 965-973.

Wells, R. D., \& Schwebel, A. I. (1987). Chronically ill children and their mothers: Predictors of resilience and vulnerability to hospitalization and surgical stress. Journal of Developmental and Behavioral Pediatrics, 8(2), 83-89.

Yildirim, İ., \& Ergene, T. (2003). Lise son sınıf öğrencilerinin akademik başarılarının yordayıcısı olarak sınav kaygısı, boyun eğici davranışlar ve sosyal destek [Social support, submissive acts and test anxiety as predictors of academic achievemen among high school students]. Hacettepe University Journal of Education, 25, 224-234. 